\title{
Implementing CLIL in a Tertiary Setting: Research on Learners' Attitudes and Perceptions
}

\author{
Evangelia V. Soulioti \\ Aristotle University of Thessaloniki \\ e.soulioti@gmail.com
}

\begin{abstract}
Content Language and Integrated Learning (CLIL) has become major educational policy promoted by the EU in reference to language learning. This paper presents the findings of a research into the attitudes and perceptions of students in a formal tertiary education setting towards CLIL implementation. For the scope of the paper, based on the data of a pilot study, a revised questionnaire was created and distributed to sixty undergraduate students in the Speech and Language Therapy Department of Epirus Institute of Technology in Greece. The participants attended an ESP course mainly based on CLIL strategies, yet all content courses are taught in the first language and there is no integration of contents and foreign language.

The purpose of this paper is twofold: first to gain insight into students' attitudes and perceptions regarding certain CLIL instructional strategies the teacher has already implemented in the ESP course and second to explore their reactions and perceptions regarding possible full CLIL implementation across the curriculum. In this respect this paper discusses ways to implement CLIL in tertiary settings, taking simultaneously into account several factors: the teaching situation, students' level of English proficiency, materials and aids, formal syllabus and curriculum. Finally it hopes to provide diagnostic feedback that will aid in the improvement of ESP course design, as well as useful data to underpin further development of the existing foreign language syllabi and curricula in higher education.
\end{abstract}

\section{Introduction}

CLIL has been developing over a period of years in Europe, but to our knowledge the measurement of students' attitudes and perceptions has not been widely explored, especially at tertiary settings. Research studies indicate that the more

\section{(cc) BY-NC-ND}


positive the students' attitudes, the higher their L2 achievement (Cenoz 2001 as cited in Lasagabaster \& Sierra 2009; Davis \& Bremer 2001 as cited in Lasagabaster \& Sierra 2009; Donitsa-Schmidt et al. 2004 as cited in Lasagabaster \& Sierra 2009). Thus, the importance of analyzing students' attitudes and perceptions toward CLIL programs when compared to the regular teaching of English as a Foreign Language is beyond any doubt (Lasagabaster \& Sierra 2009).

This paper reports on a questionnaire-based research carried out at Epirus Institute of Technology in Greece to discover whether students favor CLIL instructional strategies as a means to improve their English proficiency, possible reservations regarding these strategies as well as perceptions and reactions towards full CLIL implementation across the curriculum. The first part of the paper reviews literature and studies related to both CLIL and ESP issues. The focal point of the second part is an attempt to gain insight into the students' attitudes and perceptions towards:

(1a) certain CLIL instructional strategies the teacher has already implemented in the ESP course.

(2b) possible full CLIL implementation across the curriculum.

\section{Theoretical Background}

\subsection{Defining CLIL}

Content and Language Integrated Learning has become major educational policy promoted by the European Union in reference to language learning (Eurydice 2006). It "refers to situations where subjects or parts of subjects are taught through a foreign language with dual-focused aims, namely the learning of content and the simultaneous learning of a foreign language" (Marsh 2002). CLIL is considered as "the platform for an innovative methodological approach of far broader scope than language teaching" (Eurydice 2006), requiring that teachers should focus not just to language teaching, but to the educational process in general (Eurydice 2006). However, some scientists support that CLIL is not something new, but has been used for years under different labels ${ }^{1}$ (Mc Beath n.d.; Naves 2009). In the context

1 Content Based Learning (CBL), Task-based Approach or Task-Based Learning and Teaching (TBLT), English for Specific Purposes (ESP), Foreign Languages Across the Curriculum (FLAC) etc. 
of the present study, CLIL is regarded as an umbrella term used to describe a whole spectrum of approaches as well as features of operational practice common to a wide range of variants of bilingual education (Coyle 2007, cited in Wiesemes 2009; Mc Beath n.d; Naves 2009). Many CLIL procedures are a re-enactment of older practices which have been revised in an attempt to achieve a twofold target: to develop students' proficiency in terms of both content and language. In this respect CLIL is a more integrative approach which encompasses "any activity in which foreign language is used as a tool in the learning of a non-language subject matter in which both subject and language have a joint curricular role" (Marsh 2002:59).

Research supports that CLIL carries with it many benefits for students. It may create conditions for naturalistic language learning and provide a real-life context in the classroom (Goris 2009). It could have a positive effect on language learning by emphasizing meaning rather than form and by drastically increasing the amount of exposure to the target language (Dalton-Puffer 2007, cited in Naves 2009; Dalton-Puffer and Smitt 2007, cited in Naves 2009). CLIL is considered to build intercultural knowledge, to develop multilingual attitudes, to provide opportunities to study content through different perspectives, to diversify classroom methodology and increase learner motivation in both language and non-language subject (Marsh 2002). Overall CLIL could "nurture a 'can do' attitude towards language learning in general" (Marsh 2000 as cited in Lasagabaster \& Sierra 2009), by integrating communicative, subject, knowledge as well as learning skills (Barbero 2009).

\subsection{ESP and CLIL}

In order to attract international students and enhance employability for home students, CLIL programs have been implemented in tertiary settings (Costa and Coleman 2010), where students have been taught ESP courses so far. Some experts suggest that ESP is a special form of CLIL and that both methods enhance the simultaneous learning of content and language (Jendrych \& Wisniewska 2010). However, others suggest that there are significant differences. For instance, ESP focuses on the need to improve language within a certain discipline, whereas CLIL focuses on the learning of language and content simultaneously. Furthermore, ESP courses are considered isolated, aimed to respond mostly to language needs and focus mainly on the language teacher and learner (Ruiz-Garrido \& Fortanet-Gomez 2009). CLIL involves a larger number of stakeholders, such as discipline teachers and domain experts, since contextual factors need to be taken into account for the success of the program (Fernandez 2009; Jendrych 
\& Wisniewska 2010; Ruiz-Garrido \& Fortanet-Gomez 2009). Based on the aforementioned, CLIL could be considered as a continuum of pedagogical approaches which include ESP (Greere and Rasanen 2008, cited in RuizGarrido \& Fortanet-Gomez 2009).

\section{The Teaching Situation}

\subsection{ESP and Institutes of Technology in Greece}

The present study was conducted in a formal tertiary education setting, the Department of Speech and Language Therapy, Epirus Institute of Technology (TEI) in Greece. Epirus Institute of Technology consists of four Schools and eleven Departments situated in four Epirus cities: Ioannina, Arta, Preveza and Igoumenitsa. Speech and Language Therapy is one of the three Departments of Welfare and Health Professions School located in the city of loannina. Currently the curriculum of the department comprises introductory courses (i.e. linguistics), specialized courses (i.e. hearing disorders), clinical courses as well as ESP courses.

ESP courses at TEI cater for the needs of individual academic departments and are mostly compulsory. They are integrated as core courses in the curriculum and usually comprise lecture as well as laboratory hours. Most students that attend ESP courses at Epirus Institute of Technology are not first year students and some have already attended other ESP or General English courses. They share the same academic background and possibly certain beliefs towards EFL learning (Sifakis 2003). For instance some students believe that English can only be learned in private institutions, not in state schools. Furthermore ESP course is not a primary subject and since they have a good command in English, they can get the passing mark in the final exam (Hatzigiannoglou-Xenodoxidis 2002).

In this typical tertiary setting the medium of instruction and communication is not English, yet students are required to read content-course bibliographies in English (Spector-Cohen et al. 2001). There is a limited amount of ESP textbooks and sometimes even complete lack of instructional materials.

In reference to the Department of Speech and Language Therapy there are seven ESP courses, two of them compulsory. Until today the basic ESP course of the department has been English 6. The Course Outline involves three hours lecture and one hour lab. Attendance in lab is compulsory, but not in lecture. Therefore, missing more than certain lab hours means a drop-out of the course. 


\subsection{CLIL-ing the ESP Course}

Under these circumstances and given the many constraints blocking the integration of an institutional CLIL ${ }^{2}$, a bottom-up way was considered effective (Brady 2009), that is, to implement certain CLIL characteristics and strategies in an individual ESP class on an experimental basis. The teacher attempted to combine language and content objectives, to facilitate exposure to content knowledge at a level just beyond the learner's current knowledge (De Graaf et al. 2007) and to provide language learning in authentic and unrehearsed, yet 'scaffolded' situations (Coyle 2006, cited in Wiesemes 2009). Both meaningfocused and form-focused processing were facilitated through tasks that involve constructing meaning, activities aimed at awareness-raising of language form and corrective feedback techniques such as peer assessment (De Graaf et al. 2007). Furthermore the teacher made an effort to provide a safe learning environment, to promote active and co-operative learning and have learners use, negotiate and reconstruct subject matter meaning (Fernandez 2009).

First a pre-course needs analysis was conducted in order to gain insight into the students' perceived needs, wants and learning strategies. Additionally, information was sought concerning students' profile and background that would play a vital role in shaping the program.

In order to organize the course the English language instructor cooperated with content instructors and studied the curriculum to obtain major publications on the field as well as types of tasks students are expected to perform. Then the instructor selected representative texts from published materials and organized them into thematic units (i.e. Learning disabilities) so as to design her own course syllabus and materials.

The specific course involved three hours theory and one hour lab. In the lab students were divided into work groups so as to organize oral presentations on a variety of scientific issues (i.e. Treating Autism). Furthermore lectures were organized with the help of content instructors. Finally students were assessed on the basis of a cooperative project they had to hand out by the end of the semester. Theory section dealt with reading texts of various kinds. Students processed and discussed content area texts relevant to the issues they had already dealt with during the lab. With regard to theory they had to sit in written exams.

In this respect the following course procedures/tasks were integrated in the ESP course: organizing oral presentations related to scientific issues, group work to analyze,

$\mathbf{2}$ i.e. lack of availability and stability of the teaching staff, the type of institution and the aim of the program and the fact that language education is considered a marginalized area of less importance, not an integral part of the curriculum (Brady 2009; Costa \& Coleman 2010) 
discuss and present issues related to scientific field, peer correction and evaluation of presentations, processing and discussing content area texts, co-operative projects relevant to scientific field, the use of computer to carry out projects (web research), integration of new subject matter and expansion of subject matter students already know as well as the use of L1 just to overcome short term problems.

\section{The Instrument and Procedures Used}

For the scope of this paper a questionnaire was designed and distributed to sixty undergraduate students at the Department of Speech and Language Therapy during the winter semester of the academic year 2010-2011, after completing the ESP course.

The questionnaire is divided into four sections ${ }^{3}$; that is personal details section, current English language use, attitudes and perceptions towards CLIL instructional strategies implemented in the ESP course, attitudes and perceptions towards possible full CLIL implementation across the curriculum. The questionnaire was designed on the basis that students should not devote more than twenty minutes to fill in it. The respondent is given a set of alternative choices in the form of closed questions, mostly Yes/No and Likert scale type. Researchers suggest that the use of short, teacher-designed, class-specific questionnaire surveys to obtain course evaluation data greatly helps the teaching situation, even though teachers may often rely on intuition when planning a course (Barkhuizen 1998 as cited in Davies 2006; Spratt 1999 as cited in Davies 2006).

Data collected from the questionnaire were analyzed using the SPSS Version 17.0 software and are presented as frequencies for categorical values and as median plus interquartile range for continuous variables.

\section{The Findings}

On the basis of the information gathered from the questionnaire, the students' profile was revealed. As can be seen from Tables 1 and 2, the overwhelming majority of students were female $(96,7 \%)$ and most ranged between $21-22$ years old. This was expected, since the specific ESP course is taught in the third year of studies. Furthermore students' self-perception of their current specialist and general English proficiency was explored. The picture emerged from Table 5 conveys that General English language proficiency was 'good' or 'average' for

3 See Appendices 
most students (86,6\%). Most of them also declared average proficiency in English related to their scientific field (68,3\%). The data in Tables 3, 4 also reveal that the majority of students were certificate holders $(78,8 \%)$ and all of them had previously attended other English courses throughout their studies.

Table 1.

Age

\begin{tabular}{|l|l|l|}
\hline \multicolumn{2}{|c|}{ Age } \\
\hline Median & 22 \\
\hline Minimum & 21 \\
\hline Maximum & 25 & 32 \\
\hline \multirow{3}{*}{ Percentiles } & 50 & 21 \\
\cline { 2 - 3 } & 75 & 22 \\
\cline { 2 - 3 } & & 22 \\
\hline
\end{tabular}

Table 2.

Sex

\begin{tabular}{|l|c|c|}
\hline \multicolumn{3}{|c|}{ Sex } \\
\hline & $\mathrm{N}$ & $\%$ \\
\hline Male & 2 & 3,3 \\
\hline Female & 58 & 96,7 \\
\hline Total & 60 & 100 \\
\hline
\end{tabular}

Table 3.

Number of courses

\begin{tabular}{|l|c|c|}
\hline \multicolumn{3}{|c|}{ Number of English courses attended } \\
\hline & N & $\%$ \\
\hline All available courses & 37 & 61,7 \\
\hline Not all available courses & 23 & 38,3 \\
\hline Total & 60 & 100 \\
\hline
\end{tabular}

Table 4.

Certificate

\begin{tabular}{|l|c|c|}
\hline \multicolumn{3}{|c|}{ English language certificate } \\
\hline & N & $\%$ \\
\hline Yes & 41 & 78,8 \\
\hline No & 11 & 21,2 \\
\hline Total & 52 & 100 \\
\hline
\end{tabular}


Table 5.

Knowledge of English

\begin{tabular}{|l|c|c|c|c|c|c|c|c|}
\hline \multicolumn{7}{|c|}{ Knowledge of English } \\
\hline & \multicolumn{2}{|c|}{ Very good } & \multicolumn{2}{|c|}{ Good } & \multicolumn{2}{|c|}{ Average } & \multicolumn{2}{c|}{ Poor } \\
\hline & N & $\%$ & N & $\%$ & N & $\%$ & N & $\%$ \\
\hline General English knowledge & 3 & 5 & 26 & 43,3 & 26 & 43,3 & 5 & 8,3 \\
\hline $\begin{array}{l}\text { English language knowledge } \\
\text { related to scientific field }\end{array}$ & 0 & 0 & 13 & 21,7 & 41 & 68,3 & 6 & 10 \\
\hline
\end{tabular}

Students' responses were also useful indicators of their attitudes and perceptions regarding certain CLIL characteristics, procedures and tasks the teacher implemented in the ESP course. In Table 6 the students were asked to respond whether nine CLIL procedures and tasks were easy, pleasant, useful for English language and useful for developing content knowledge. As observed from Table 6 and Figure 1, nearly 40\% of the respondents' encountered difficulty processing texts related to their scientific field, whereas almost half of them

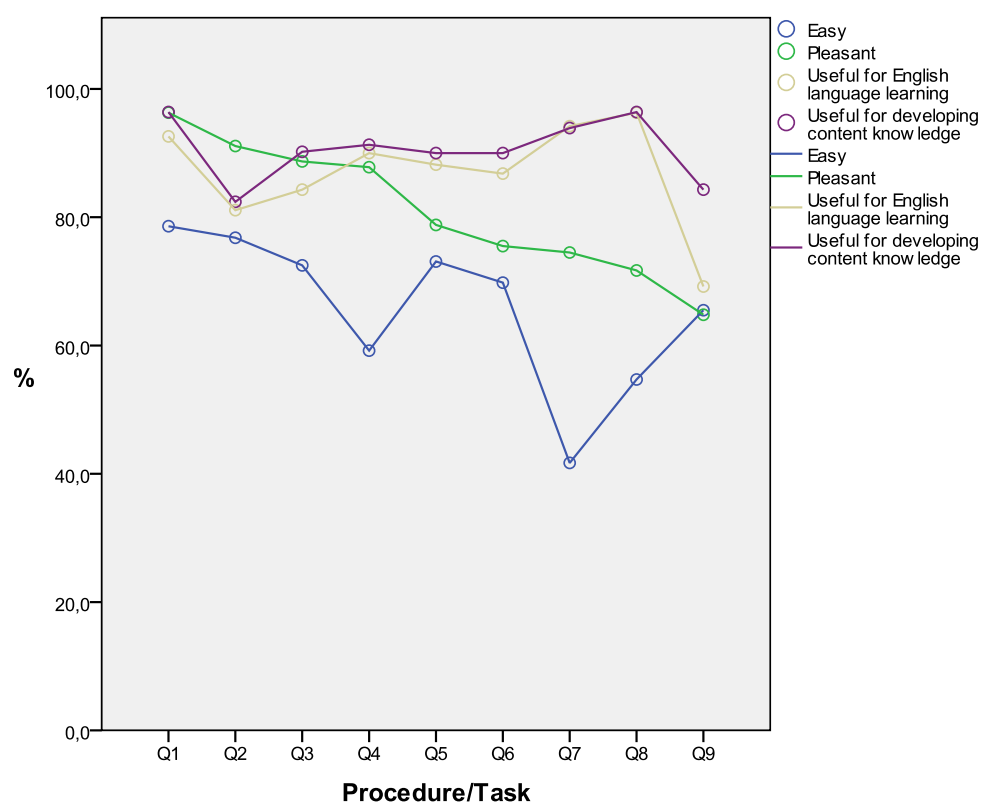

Figure 1. CLIL Procedures and Tasks 
Table 6.

CLIL Procedures and Tasks

\begin{tabular}{|c|c|c|c|c|c|c|c|c|}
\hline \multirow[t]{2}{*}{ Procedures/tasks } & \multicolumn{2}{|c|}{$\begin{array}{l}\text { Evaluated as } \\
\text { easy }\end{array}$} & \multicolumn{2}{|c|}{$\begin{array}{l}\text { Evaluated as } \\
\text { pleasant }\end{array}$} & \multicolumn{2}{|c|}{$\begin{array}{l}\text { Evaluated } \\
\text { as useful } \\
\text { for English } \\
\text { language } \\
\text { learning }\end{array}$} & \multicolumn{2}{|c|}{$\begin{array}{l}\text { Evaluated } \\
\text { as useful for } \\
\text { developing } \\
\text { content } \\
\text { knowledge }\end{array}$} \\
\hline & $\mathrm{N}$ & $\%$ & $\mathrm{~N}$ & $\%$ & $\mathrm{~N}$ & $\%$ & $\mathrm{~N}$ & $\%$ \\
\hline $\begin{array}{l}\text { 1. Presentations related } \\
\text { to scientific issues } \\
\text { during the lab }\end{array}$ & 44 & 78,6 & 52 & 96,3 & 50 & 92,6 & 53 & 96,4 \\
\hline $\begin{array}{l}\text { 2. Group work to analyze } \\
\text { and discuss issues } \\
\text { related to your scientific } \\
\text { field. }\end{array}$ & 40 & 76,9 & 51 & 91,1 & 43 & 81,1 & 42 & 82,4 \\
\hline $\begin{array}{l}\text { 3. Group work to present } \\
\text { issues related to your } \\
\text { scientific field. }\end{array}$ & 37 & 72,5 & 47 & 88,7 & 43 & 84,3 & 46 & 90,2 \\
\hline $\begin{array}{l}\text { 4.Oral presentations on } \\
\text { issues related to your } \\
\text { scientific field }\end{array}$ & 29 & 59,2 & 43 & 87,8 & 45 & 90 & 42 & 91,3 \\
\hline $\begin{array}{l}\text { 5. Recording students' } \\
\text { views according to their } \\
\text { oral presentations }\end{array}$ & 38 & 73,1 & 41 & 78,8 & 45 & 88,2 & 45 & 90 \\
\hline $\begin{array}{l}\text { 6. Assessing and } \\
\text { discussing presentations } \\
\text { made by other groups. }\end{array}$ & 37 & 69,8 & 40 & 75,5 & 46 & 86,8 & 45 & 90 \\
\hline $\begin{array}{l}\text { 7. Processing scientific } \\
\text { texts. }\end{array}$ & 20 & 41,7 & 35 & 74,5 & 49 & 94,2 & 46 & 93,9 \\
\hline $\begin{array}{l}\text { 8. Projects relevant to } \\
\text { your scientific field. }\end{array}$ & 29 & 54,7 & 38 & 71,7 & 52 & 96,3 & 53 & 96,4 \\
\hline $\begin{array}{l}\text { 9. The use of computer } \\
\text { to carry out projects } \\
\text { relevant to your } \\
\text { scientific field. }\end{array}$ & 36 & 65,5 & 35 & 64,8 & 36 & 69,2 & 43 & 84,3 \\
\hline
\end{tabular}

encountered difficulty conducting projects. As indicated by the responses the other seven procedures were considered as easy by most students, especially presentations related to scientific issues. All CLIL procedures and tasks pleased students, as Table 6 and Figure 1 reveal. In fact learners' attitude towards organizing presentations related to scientific issues and group work was overwhelmingly positive. Surprisingly the least favored task was the use of computer to carry out projects related to their scientific field $(64,8 \%)$. Summarizing the feedback from Table 6 and Figure 1, it is evident that the overwhelming majority also declared that CLIL instructional tasks and procedures were useful for developing language as well as content knowledge. Furthermore, with regard to limited use of mother tongue during the course it was considered useful $(81,7 \%)$ and easy $(85 \%)$, for the majority of students (Table 7). It is also evident from Table 8 that students used less English than expected, since less than one third of them declared discussing 
and negotiating with their classmates in English. However, a considerable amount $(58,3 \%)$ used the target language to clarify any queries or issues raised. Finally, as observed from Table 9, the overwhelming majority stated that the integration of content related to other curriculum subjects helped them develop language as well as content knowledge.

Table 7.

Use of mother tongue in class

\begin{tabular}{|l|c|c|}
\hline \multicolumn{3}{|c|}{ Limited use of mother tongue... } \\
\hline was useful & $\mathbf{N}$ & $\%$ \\
\hline was difficult & 49 & 81,7 \\
\hline pleased me & 9 & 15 \\
\hline
\end{tabular}

Table 8.

English in the classroom

\begin{tabular}{|l|c|c|}
\hline \multicolumn{3}{|c|}{ I used English in the classroom to... } \\
\hline & $\mathbf{N}$ & $\%$ \\
\hline clarify questions/issues & 35 & 58,3 \\
\hline discuss with my classmates on a scientific issue & 18 & 30 \\
\hline negotiate with other group members & 15 & 25 \\
\hline discuss scientific articles and books and the author's views & 5 & 8,3 \\
\hline make off-task comments & 9 & 15,5 \\
\hline
\end{tabular}

Table 9.

Integration of Content

\begin{tabular}{|l|c|c|c|c|c|c|}
\hline \multicolumn{7}{|c|}{ Integration of content } \\
\hline & \multicolumn{2}{|c|}{ Agree } & $\begin{array}{l}\text { Neither agree } \\
\text { nor disagree }\end{array}$ & \multicolumn{2}{c|}{ Disagree } \\
\hline & N & $\%$ & N & $\%$ & N & $\%$ \\
\hline $\begin{array}{l}\text { Integration of content related to other } \\
\text { curriculum subjects is helpful in language } \\
\text { development }\end{array}$ & 50 & 83,3 & 9 & 15 & 1 & 1,7 \\
\hline $\begin{array}{l}\text { Integration of content related to } \\
\text { other curriculum subjects is helpful in } \\
\text { developing knowledge of other content } \\
\text { courses }\end{array}$ & 50 & 83,3 & 8 & 13,3 & 2 & 3,3 \\
\hline
\end{tabular}

Students' perceptions and attitudes regarding full CLIL implementation across the curriculum were also explored. The findings from Table 10 suggest that the majority of students preferred to attend 'some courses' 'in some semesters' 
(as opposed to 'many' 'throughout their studies') held by content teachers in English. Less than one third of students wouldn't like to attend courses held by content teachers in English. Also few students responded positively to full CLIL implementation across the curriculum. Moreover, as can be seen from Table 11, the great majority of students supported that attending lectures in English is a good way to improve language $(93,3 \%)$ as well as content knowledge $(86,7 \%)$ and were greatly interested in collaborative projects with foreign Universities in the context of European programs (80\%). Most students also supported that they liked learning about their science using English and that they would like to attend bilingual courses (75\% and $66,7 \%$ respectively). Finally less than half of the respondents $(41,7 \%)$ showed interest in processing texts or doing written projects in English in the context of other curriculum subjects.

Table 10.

Attendance of Content Courses in English

\begin{tabular}{|l|c|c|}
\hline \multicolumn{3}{|c|}{ Attendance of content courses held by content teachers in English } \\
\hline & \multicolumn{2}{|c|}{$\begin{array}{c}\text { It would be interesting to attend } \\
\text { courses held by content teachers in English }\end{array}$} \\
\hline & N & $\%$ \\
\hline Yes, many course & 4 & 6,7 \\
\hline Yes, some courses & 38 & 63,3 \\
\hline No & 18 & 30 \\
\hline Throughout my studies & 6 & 10 \\
\hline In some semesters & 40 & 66,7 \\
\hline Not at all & 14 & 23,3 \\
\hline
\end{tabular}

Table 11.

Statements regarding full CLIL implementation

\begin{tabular}{|l|c|c|}
\hline Statements regarding full CLIL implementation & \multicolumn{2}{|c|}{ Yes } \\
\hline & N & $\%$ \\
\hline I would like to attend bilingual courses in English and Greek & 40 & 66,7 \\
\hline Attending a lecture in English is a good way to improve my English & 56 & 93,3 \\
\hline $\begin{array}{l}\text { Attending a lecture in English is a good way to improve knowledge of issues } \\
\text { related to speech therapy }\end{array}$ & 52 & 86,7 \\
\hline $\begin{array}{l}\text { It would be interesting to process texts or do written projects in English in the } \\
\text { context of other curriculum subjects }\end{array}$ & 25 & 41,7 \\
\hline I like learning about my science using English & 45 & 75 \\
\hline $\begin{array}{l}\text { It would be interesting to participate in projects with other universities in the } \\
\text { context of European programs }\end{array}$ & 48 & 80 \\
\hline
\end{tabular}




\section{Discussion and Implications}

The general overview of the data illustrated that students favored the dual focus of CLIL, that is the integration of content and language. On the whole the respondents strongly felt that integration of content related to other curriculum subjects was beneficial towards developing language as well as content knowledge. In this respect CLIL has a twofold aim at tertiary settings: the academic development of learners and the attainment of academic language proficiency (Naves 2009). Taking also into account that students' self-reported language proficiency indicated the need to integrate more ESP and even General English courses in the curriculum, CLIL seems appropriate to accommodate for any time, budget, administration and other constraints which hinder the implementation of supplementary English courses.

It was also evident that students favored most CLIL strategies and procedures. The overwhelming majority of students appreciated the more interactive nature of learner-centered activities (Ruis-Garrido \& Fortanet-Gomez 2009) and felt confident with tasks involving active participation, collaboration and research skills. In line with other studies CLIL strategies and procedures provided learners with various opportunities to share knowledge and ideas through social interaction (Pistorio 2010) and contributed to the development of social, group and in general cooperative learning skills (Wiesemes 2009). Thus by integrating CLIL strategies the apparent difficulties teachers face in a large heterogeneous class could be turned into a positive learning experience. On the basis of this and given the flexibility of the tertiary curricula the ESP designer could use CLIL strategies to adapt syllabus, content and types of activities.

Consistent with other studies the results confirmed that CLIL-based programs help to foster positive attitudes towards language learning (Bebenroth \& Redfield 2004; Lasagabaster \& Sierra 2009) and raise learners' motivation in both language and non-language subject. The results indicated that students felt comfortable with CLIL tasks and procedures and their confidence in both language and content knowledge was increased (Wiesemes 2009). Also students were highly motivated to learn the target language, possibly due to the fact that language was used in real-life settings (Infante et al. 2009) and students saw a purpose for mastering it (Vlachos 2009).

The most important conclusion to be drawn however, is that most students showed preference for medium CLIL exposure, not a fully dual approach or full CLIL implementation across the curriculum. Therefore there is sufficient support among the student body to recommend at first elective courses held in English (Bebenroth $\&$ Redfield 2004), taking into account that CLIL programs are considered effective when optional not imposed (Swain \& Lapkin 1982, cited in Naves 2009). Given this a bottom-up way of promoting CLIL is considered more effective in this specific teaching context. According to Brady (2009) this means 
to develop language and content integration in individual classes, as is the case with this research, where any positive results can be detected and progressively lead to greater adoption of CLIL across the curriculum. In this respect before attempting full CLIL implementation at Epirus Institute of Technology, subject teachers together with language teachers could decide which subjects are more suitable to be taught through English. Also taking into account students' preference for collaborative work, certain activities, assignments or projects could be coordinated by both language and content teachers (Ruis-Garrido \& Fortanet-Gomez 2009), since experts suggest that CLIL programs require joint effort of all members involved (Naves 2009). As Carloni (2010) suggests CLIL requires careful methodological planning and this should be brought to the attention of the content teachers, otherwise the quality of teaching and learning will not meet the expectations. Overall this would help to break down departmental barriers, enhance cooperation among members with regard to pedagogical and methodological issues and contribute to the development of integrated curricula (Wiesemes 2009).

Learner's responses to survey items have led to important conclusions regarding CLIL implementation in tertiary settings. However, there is lack of research on CLIL at tertiary level in Greece and students' attitudes towards CLIL programs should be examined in a more systematic way if we are to draw safe conclusions. The research also involves only one department of Epirus Institute of Technology, where students attended a course based on certain CLIL strategies and procedures and there hasn't been a constant exposure to CLIL for a considerable amount of time. In addition the questionnaire used is not an infallible instrument and the potential for teacher bias and subjectivity in item creation definitely exists (Block 1998, cited in Davies 2006).

This paper examined different facets of CLIL and the learners' attitudes towards them in an attempt to discuss effective ways to implement CLIL in tertiary settings. While the findings are directly applicable only to learners with similar characteristics of those in this research, it is hoped that the process described will provide insight to educational designers to investigate efficient ways of implementing CLIL in tertiary settings. A revised survey could also include items looking at students' interests to enroll in bilingual courses when the exam or part of it is in English (Bebenroth \& Redfield 2004). Furthermore it would be crucial to explore the relationship between learners' attitudes towards CLIL and self-reported "General English knowledge". 


\section{References}

Barbero, T., A. Damascelli and M.-B. Vittoz. 2009. Integrating the Common European Framework for Reference (CEFR) with CLIL. In D. Marsh, P. Mehisto, D. Wolff, R. Aliaga, T. Asikainen, M.J. Frigols-Martin, S. Hughes and G. Lange (eds), CLIL Practice: Perspectives from the field. CCN, University of Syvaskyla: Finland, 102-109.

Bartik, K., C. Maerten, I. Tudor and J. Valcke. 2009. A Discussion Brief of Content and Language Integrated Learning (CLIL) at the Faculty of Applied Sciences. http://www.ulb.ac.be/facs/philo/whoswho/16743.html

Bebenroth, R. and M. 'Rube' Redfield. 2004. Do OUE Students Want ContentBased Instruction? An Experimental Study. Osaka Keidai Ronshu 55(4): 91-96. http://www.bebenroth.eu/Downloads/ CententBasedlnstrucRube55.04DaiKeiD ai.pdf

Brady, A. 2009. An Integrated Approach to Content and Language Study: Citizenship Development and Society Building. In D. Marsh, P. Mehisto, D. Wolff, R. Aliaga, T. Asikainen, M.J. Frigols-Martin, S. Hughes and G. Lange (eds), CLIL Practice: Perspectives from the field. CCN, University of Syvaskyla: Finland, 55-61.

Carloni, G. 2010. Analyzing a CLIL Classroom in a University setting. CCN CLIL Proceedings: Uncovering CLIL Quality by CLIL Practitioners. Rovaniemi: Finland.

Costa, F. and J. Coleman. 2010. Integrating Content and Language in Higher Education in Italy: Ongoing Research. International CLIL Research Journal 1(3): $19-29$.

Davies, A. 2006. What do learners really want from an EFL course? ELT Journal 60(1): 3-12. 
De Graaff, R., G.J. Koopman, Y. Anikina and G. Westhoff. 2007. Identifying Effective L2 Pedagogy in Content and Language Integrated Learning (CLIL). The International Journal of Bilingual Education and Bilingualism 10(5): 603-624.

Eurydice. 2006. Content and Language Integrated Learning (CLIL) at School in Europe. Belgium: European Commission. http://www.eurydice.org

Fernandez, D. 2009. CLIL at the University Level: Relating Language Teaching with and through Content Teaching. Latin American Journal of Content and Language Integrated Learning 2(2):10-26.

Goris, J. 2009. English in Mainstream European Secondary Schools: Content and Language Integrated Learning (CLIL). In D. Marsh, P. Mehisto, D. Wolff, R. Aliaga, T. Asikainen, M.J. Frigols-Martin, S. Hughes and G. Lange (eds), CLIL Practice: Perspectives from the field. CCN, University of Syvaskyla: Finland, 28-33.

Guerrini, M. 2009. CLIL Materials as Scaffolds to Learning? In D. Marsh, P. Mehisto, D. Wolff, R. Aliaga, T. Asikainen, M.J. Frigols-Martin, S. Hughes and G. Lange (eds), CLIL Practice: Perspectives from the field. CCN, University of Syvaskyla: Finland, 74-89.

Hatzigiannoglou-Xenodoxidis, T. 2002. An ESP Curriculum for Greek EFL students of Computing: A New Approach. English for Specific Purposes 1. http://www.espworld.infocontents.htm

Infante, D., G. Benvenuto and E. Lastrucci. 2009. The Effects of CLIL from the Perspective of Experienced Teachers. In D. Marsh, P. Mehisto, D. Wolff, R. Aliaga, T. Asikainen, M.J. Frigols-Martin, S. Hughes and G. Lange (eds), CLIL Practice: Perspectives from the field. CCN, University of Syvaskyla: Finland, 156-163.

Jendrych, E. and H. Wisniewska. 2010. ESP: How to design challenging tasks for Adult Learners. International Conference "ICT for Language Learning". Retrieved 2 February 2010 from http://www.pixel-online.net/ ICT4LL2010/ conferenceproceedings.php

Lasagabaster, D. and J.M. Sierra. 2009. Language Attitudes in CLIL and Traditional EFL Classes. International CLIL Research Journal 1(2):4-17.

Marsh, D. 2002. Content and Language Integrated Learning: The European Dimension - Actions, Trends and Foresight Potential. Retrieved 10 February 2010 from http://ec.europa.eu/education/languages/pdf/doc491_en.pdf 
Mc Beath, N. n.d. CLIL or Deep Level ESP? Retrieved 12 February 2011 from http://www.developingteachers.com/articles_tchtraining/clil1_neil.htm

Naves, T. 2009. Effective Content and Language Integrated Programmes (CLIL). In Y. Ruiz de Zarobe and R. Jimenez Catalan (eds), Content and Language Integrated Learning: Evidence from Research in Europe. Bristol: Multilingual Matters, 22-40.

Pistorio, M.I. (2010). A blend of CLIL and cooperative learning creates a socially constructed learning environment. Latin American Journal of Content $\&$ Language Integrated Learning 3(1):1-10.

Ruiz Garrido, M. and I. Fortanet-Gomez. 2009. Needs Analysis in a CLIL Context: A Transfer from ESP. In D. Marsh, P. Mehisto, D. Wolff, R. Aliaga, T. Asikainen, M.J. Frigols-Martin, S. Hughes and G. Lange (eds), CLIL Practice: Perspectives from the field. CCN, University of Syvaskyla: Finland, 179-188.

Sifakis, N. 2003. Applying the Adult Education Framework to ESP Curriculum Development: An Integrative Model. English for Specific Purposes 22: 195-211.

Spector-Cohen, E., M. Kirschner and C. Wexler. 2001. Designing EAP Reading Courses at the University Level. English for Specific Purposes 26:367-386. http://www.esp-world.infocontents.htm

Vlachos, K. 2009. The Potential of Information Communication Technologies (ICT) in Content and Language Integrated Learning (CLIL): The case of English as a Second/Foreign Language. In D. Marsh, P. Mehisto, D. Wolff, R. Aliaga, T. Asikainen, M.J. Frigols-Martin, S. Hughes and G. Lange (eds), CLIL Practice: Perspectives from the field. CCN, University of Syvaskyla: Finland, 189-198.

Wiesemes, R. 2009. Developing Theories and Practices in CLIL: CLIL as PostMethod Pedagogies? In Y. Ruiz de Zarobe and R. Jimenez Catalan (eds), Content and Language Integrated Learning: Evidence from Research in Europe. Bristol: Multilingual Matters, 41-62. 


\section{Appendix}

\section{Questionnaire English 6}

Dear student,

This questionnaire is about the teaching and learning procedure regarding the course English 6. Your answers will help me organize better the course in the future and to explore your views regarding contemporary trends in the field of foreign language teaching.

Therefore I would appreciate it if you would take some time to answer the questions. Your answers will be confidential.

Thank you,

Dr. Soulioti Evangelia

\section{PERSONAL INFORMATION}

Age:

Sex: $\quad$ Male $\square \quad$ Female $\square$

\section{KNOWLEDGE OF ENGLISH LANGUAGE}

\section{English courses you attended during your studies.}

- English for beginners $\square$

- English 1 口

- English 2 口

- English 3 口

- English 4 $\square$

- English 5 口

2. Do you hold any certificate and if yes, which exactly?

3. How would you rate your knowledge in general English?

Very good $\square \quad$ Good $\square \quad$ Average $\square \quad$ Poor $\square$

4. How would you rate your English language knowledge related to your scientific field?

Very good $\square \quad$ Good $\square \quad$ Average $\square \quad$ Poor $\square$ 
TEACHING PROCEDURE

5. How would you evaluate the following course procedures/tasks?

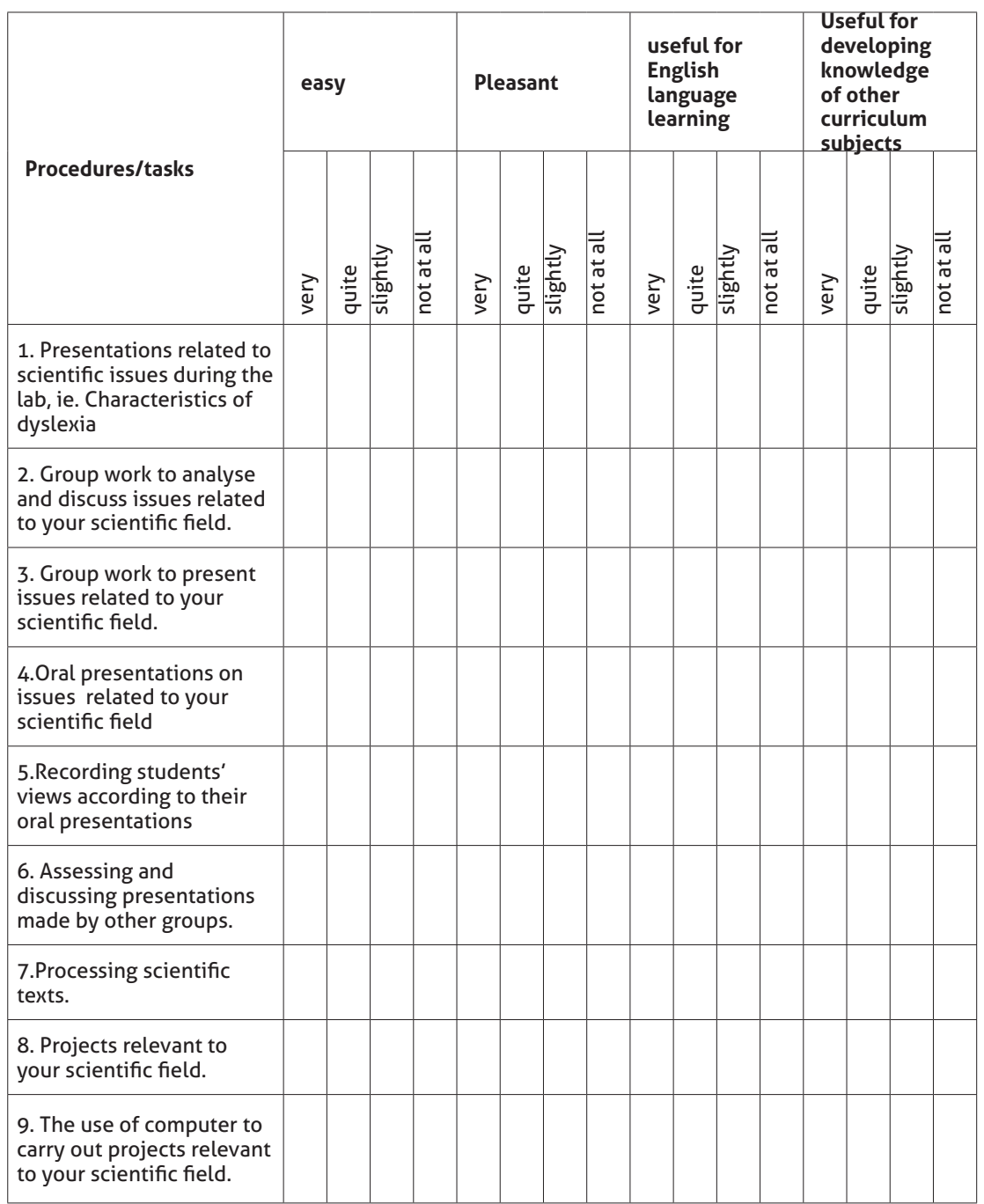

6. The teacher avoided the use of mother tongue. This..
A. was useful
B. was difficult
C. pleased me. 
7. I used English in the classroom to:
A. clarify questions/issues
B. discuss with my classmates on a scientific issue.
C. negotiate with other group members.
D. discuss the author's views of scientific articles and books..
E. to make off-task comments.

8. The integration and processing of content related to other school courses in the English course helped me learn the language.
Agree $\square$
Neither agree nor disagree $\square$
Disagree $\square$

9. The integration and processing of content related to other school courses in the English course helped me develop knowledge of other content courses.
Agree $\square$
Neither agree nor disagree $\square$
Disagree $\square$

\section{INTEGRATING ENGLISH LANGUAGE ACROSS THE CURRICULUM}

10. Choose one of the three

A. It would be interesting to attend Speech and Language Therapy courses held by content teachers in English.

Yes, many courses $\square \quad$ Yes, some courses $\square \quad$ No. $\square$

B. It would be interesting to attend Speech and Language Therapy courses held by content teachers in English.

Throughout my studies $\square \quad$ In some semesters $\square \quad$ Not at all $\square$

11. I would tike to attend bilingual courses in English and Greek

Yes $\quad \quad$ No $\quad$

12. Attending a lecture in English is a good way to improve my English.

Y

es $\quad \mathrm{Nor}$

13.Attending a lecture in English is a good way to improve knowledge of issues related to speech therapy.

Yes $\quad$ No $\quad$ N 
14. It would be interesting to process texts or do written projects in English in the context of other curriculum subjects.

Yes $\quad$ No $\quad$

15. I like learning about my science using English.

Yes $\quad$ No $\quad$ N

16. It would be interesting to participate in projects with other universities in the context of European programs.

Yes $\quad$ No $\quad$ ( 